\title{
Pengembangan Tanaman Kenaf (Hibiscus cannabinus L) pada Lahan Pasca Tambang Batubara
}

\author{
Roby $^{1}$, Yuanita ${ }^{1}$, F. Silvi Dwi Mentari ${ }^{1}$
}

1)Program Studi Budidaya Tanaman Perkebunan, Politeknik Pertanian Negeri Samarinda Korespondensi: robybtp1@gmail.com

\begin{abstract}
Post coal mining activities in the village of Tanah Datar Muara Badak District, East Kalimantan Province, left vast vacant land. One of efforts to utilize the post-mining land through experimentation with kenaf (Hibiscus cannabinus L.) plant. Kenaf is a stem-fiber producer from the Malvaceae family, and currently receiving industrial attention. Kenaf plant can be utilized entirely, as industrial raw material with high commercial value. Kenaf also environmental-friendly and can absorb carbon dioxide from the atmosphere, therefore it is suitable to be developed as environmental-friendly industrial raw material. Kenaf species can grow in land with low nutrient status and toxic chemicals. The results show that kenaf plant can grow well on post coal mine land that has been treated previously with biochar and fertilizer. Biochar $100 \mathrm{Kg}$ per plot in dosage combining with Mucuna sp.that spacing $30 \times 30 \mathrm{~cm}$ give the best result for Kenaf growth both in diameter and plant height.
\end{abstract}

Keywords: land use, coal mine, kenaf, mucuna

\section{PENDAHULUAN}

Tanah galian batubara umumnya tersusun terbalik dari susunan awalnya. Tanah lapisan atas (top soil) berada di bawah tanah lapisan bawah (sub soil). Umumnya bahan-bahan ini ditumpuk diatas tanah-tanah yang produktif sehingga dapat menghambat pertumbuhan tanaman dan menurunkan produktivitas tanah. Umumnya areal bekas timbunan batubara ini dalam beberapa tahun pertama sulit ditumbuhi vegetasi karena berbagai macam kendala.

Beberapa kendala fisik yang dihadapi dalam upaya reklamasi tanah bekas penambangan batubara yakni: tanah terlalu padat, struktur tanah tidak mantap, aerasi dan drainase tanah jelek, serta lambat meresapkan air. Selain itu kendala kimia seperti $\mathrm{pH}$ sangat masam, tingginya kadar garam, dan rendahnya tingkat kesuburan tanah merupakan pembatas utama dalam mereklamasi area tanah timbunan. Konsekuensinya diperlukan input yang relatif besar (seperti: pupuk buatan dan pupuk organik, berbagai senyawa senyawa kimia untuk mengendalikan hama dan penyakit, sarana dan prasarana untuk menjamin ketersediaan air bagi tanaman) untuk memperbaiki kualitas atau menyehatkan ekosistem tanah agar dapat mendukung pertumbuhan dan perkembangan tanaman (Margarettha, 2010).

Reklamasi lahan bekas tambang memerlukan pendekatan dan teknologi yang berbeda tergantung atas sifat gangguan yang terjadi dan juga peruntukannya (penggunaan setelah proses reklamasi). Secara umum, tahapan reklamasi adalah konservasi top soil, penataan lahan, pengelolaan sedimen dan pengendalian erosi, penanaman tanaman penutup tanah, penanaman tanaman pionir, dan penanggulangan logam berat (Dariah dkk., 2010).

Salah satu upaya pemanfaatan lahan pasca kegiatan penambangan batubara di desa Tanah Datar Kecamatan Muara Badak Provinsi Kalimantan Timur pasca adalah dengan percobaan pengembangan tanaman kenaf (Hibiscus cannabinus L.). Sebelum dilaksanakan penanaman kenaf, tanah bekas lahan tambang batubara tersebut telah direklamasi dengan cara ditanami Mucuna sp dan diberikan pembenah tanah biochar. Pengembangan tanaman kenaf diharapkan 
dapat menjadi pertimbangan pemanfaatan lahan kosong eks tambang batubara. Selain itu, keberhasilan budidaya tanaman kenaf dapat memberikan informasi mengenai kemungkinan pemanfaatan tanaman pertanian dan perkebunan lainnya setelah melalui fase reklamasi lahan yang tepat.

\section{BAHAN DAN METODE}

Bahan yang dipakai dalam penelitian ini adalah benih kenaf (Hibiscus cannabinus L) jenis varietas KR 11 (Karang Ploso) dari Balai Penelitian Tanaman Serat Malang. Alat yang dipakai adalah baskom untuk uji viabilitas benih kenaf, tugal untuk menanam benih kenaf, gembor untuk penyiraman, microcaliper dan meteran untuk mengukur diameter dan tinggi tanaman kenaf.

Percobaan dibagi kedalam 4 plot yang berukuran $2 \times 3 \mathrm{~m}$ (Gambar 1). Plot-plot tersebut dibagi menjadi: 2 plot telah ditanami Mucuna sp dengan jarak tanam $30 \times 30 \mathrm{~cm}$ dan 40 x $40 \mathrm{~cm}$, dan 2 plot yang lain kombinasi Mucuna sp jarak tanam 30 x $30 \mathrm{~cm}$ dengan Biochar $100 \mathrm{~kg} /$ plot dan kombinasi Mucuna sp jarak tanam $40 \mathrm{~cm}$ x $40 \mathrm{~cm}$ dengan Biochar $100 \mathrm{~kg} /$ plot.

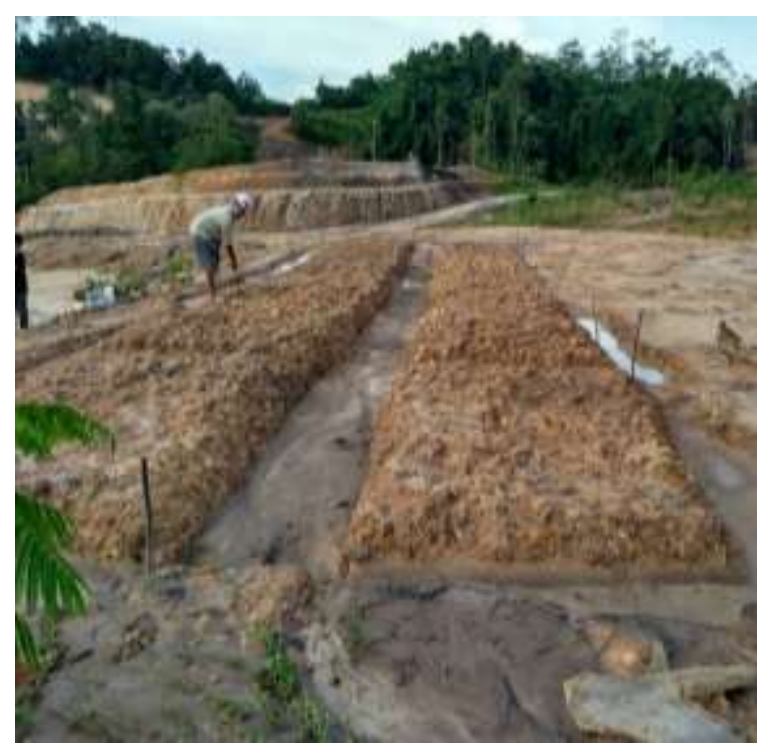

Gambar 1 Plot penelitian di lokasi lahan Bekas Tambang Batubara
Sebelum ditanam, dilakukan uji viabilitas benih untuk mengetahui seberapa besar tingkat pertumbuhan benih tersebut, selanjutnya penanaman dilakukan dengan cara tugal sebanyak 3 biji per lubang dengan jarak tanam 35 x $35 \mathrm{~cm}$. Penjarangan dilakukan untuk menyisakan 1 (satu) tanaman tiap lubang tanam, dilakukan pada tanaman berumur 10 hari setelah tanam.

Pemeliharaan yang dilakukan meliputi penyiraman dan penyiangan serta sesekali melepaskan lilitan dari Mucuna sp. (Gambar 2). Penyiraman dilakukan setiap hari pada waktu sore hari jika tidak ada hujan, penyiraman dilakukan sampai tanah dalam keadaan kapasitas lapang atau kebutuhan air tanaman terpenuhi, penyiangan dilakukan tergantung banyak sedikitnya gulma.

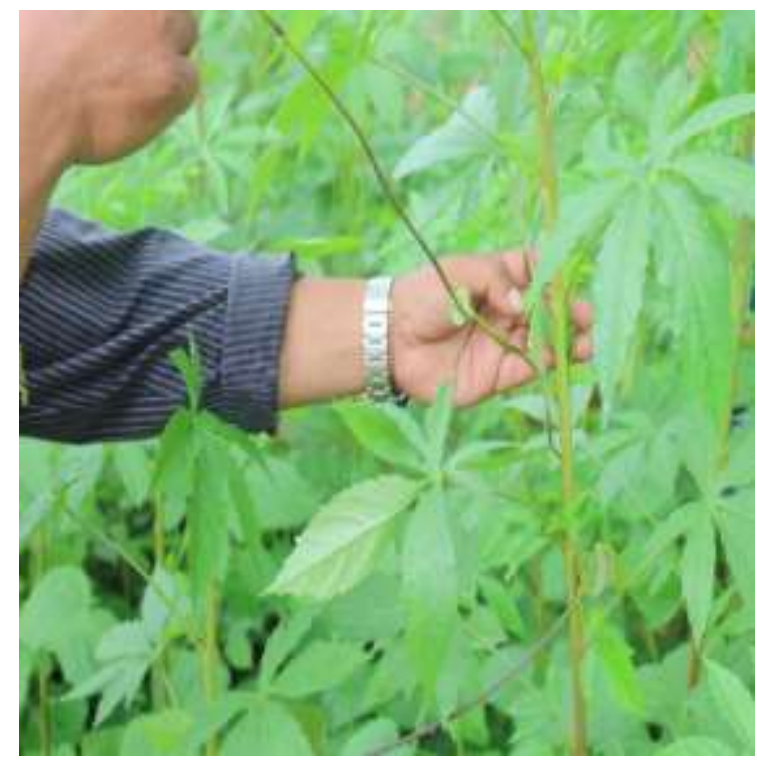

Gambar 2 Pelepasan lilitan Mucuna sp dari tanaman kenaf

Pengambilan data dengan parameter diameter dan tinggi tanaman kenaf, pada umur 30 hari setelah tanam, 45 hari setelah tanam dan 60 hari setelah tanam dan selanjutnya dihitung nilai rataan serta dibuat grafik yang membandingkan pertambahan pertumbuhan tanaman kenaf hasil pengukuran diameter dan tinggi yang ditanam 
pada plot penelitian dengan model reklamasi lahan bekas tambang batubara yang berbeda.

\section{HASIL DAN PEMBAHASAN}

\subsection{Perbaikan Karakteristik Tanah}

Upaya peningkatan produktivitas sektor pertanian dan perkebunan menjadi sangat penting karena permintaan hasil yang semakin tinggi. Disisi lain penyempitan lahan pertanian selalu terjadi disebabkan karena adanya alih fungsi lahan dari pertanian menjadi lahan non-pertanian diantaranya disebabkan kegiatan aktivitas pertambangan (batubara, minyak bumi, emas, timah, dan lain-lain).

Pengembangan tanaman kenaf di lahan bekas tambang batubara Desa Tanah Datar Kecamatan Muara Badak Kabupaten Kutai Kertanegara Provinsi Kalimantan Timur merupakan upaya pemanfaatan lahan dalam tahap reklamasi sehingga nantinya diharapkan layak untuk dimanfaatkan dalam berbagai bidang yang bernilai ekonomis dan ekologis.

Aplikasi biochar ke dalam tanah berpengaruh terhadap meningkatnya kesuburan tanah. Hal ini dimungkinkan karena biochar yang berpori menjadi tempat berkembangnya organisme tanah yang berguna untuk mendaur bahan organik di dalam tanah, dan tingginya daya tahan biochar di dalam tanah yaitu bisa mencapai 1000 tahun untuk terurai (Laird, 2008). Selain itu peran biochar bagi tanah adalah menjaga kelembapan dan meningkatkan kesuburan tanah. Karakteristiknya yang memiliki pori pori yang berguna mencegah aliran permukaan (run-off) memungkinkan untuk turut mencegah terjadinya kehilangan unsur hara yang berguna bagi tanaman sehingga pencucian unsur hara $\mathrm{N}$ dapat dikurangi secara signifikan dengan menambahkan biochar ke dalam tanah (Steiner, 2007).

Tanaman Mucuna sp. merupakan tanaman legume cover crop yang biasa digunakan dalam pelaksanaan penelitian rehabilitasi lahan maupun aplikasi di lapangan. Tanaman Mucuna sp. selain pertumbuhannya cepat, juga menghasilkan bahan organik yang cukup banyak terutama pada bagian daun. Bahan organik merupakan sumber nitrogen tanah yang utama dan berperan cukup besar dalam proses perbaikan sifat fisik, kimia, dan biologi tanah.

Bahan organik sisa tanaman yang ditambahkan ke dalam tanah dan mengalami beberapa kali fase perombakan oleh organisme tanah untuk menjadi humus atau bahan organik tanah. Pengelolan bahan organik dari sisa tanaman secara terpadu merupakan cara pengeloaan tanah untuk meningkatkan efisiensi pupuk, produktivitas tanah dan menjamin kemantapan produksi tinggi dan berkelanjutan (Juarsah, 2015).

Upaya pemberian biochar dan penanaman LCC jenis Mucuna sp pada tahap sebelum penanaman kenaf dapat meningkatkan kesuburan tanah, hal ini merupakan salah satu cara reklamasi yang dianggap tepat sehingga lahan bekas tambang batubara dapat difungsikan untuk budidaya kenaf.

\subsection{Pertumbuhan Tanaman Kenaf}

Sastrosupadi dkk (1996) menyatakan bahwa tanaman kenaf merupakan tanaman yang ramah lingkungan karena banyak menyerap $\mathrm{CO}_{2}$, sehingga sesuai untuk dikembangkan sebagai bahan baku industri yang ramah lingkungan. Tanaman kenaf dapat tumbuh hampir pada semua tipe tanah, tetapi tanah yang ideal untuk kenaf yaitu tanah lempung berpasir atau lempung liat berpasir dengan drainase yang baik.

Tanaman kenaf (Hibiscus cannabinus L.) merupakan tanaman penghasil serat batang dari famili Malvaceae, yang saat ini sedang mendapat perhatian dari dunia industri, karena semua bagian tanamannya dapat dijadikan bahan baku industri yang bernilai komersial tinggi. Hasil pengolahan serat kenaf, antara lain digunakan sebagai bahan baku pembuatan fibre board, fibre drain, geo- 
textile, bahan dasar pulp, dan kertas (Purwati, 2009).

Grafik rata-rata pertumbuhan diameter tanaman kenaf (Gambar 3) menunjukkan bahwa pertumbuhan paling baik adalah pada plot yang diberikan pembenah tanah Biochar sebanyak $100 \mathrm{~kg} /$ plot yang dikombinasikan dengan penanaman LCC jenis Mucuna sp dengan jarak tanam $30 \mathrm{~cm}$ x $30 \mathrm{~cm}$. Pemilihan pemberian pembenah tanah biochar ini telah dicobakan sebelumnya di mana berdasarkan uji DMRT di antara kontrol, pemberian biochar $25 \mathrm{~kg} /$ plot, $50 \mathrm{~kg} /$ plot, $75 \mathrm{~kg}$ plot dan $100 \mathrm{~kg} /$ plot maka pemberian pembenah tanah biochar $100 \mathrm{~kg} /$ plot memberikan hasil paling baik terhadap pertumbuhan kenaf.

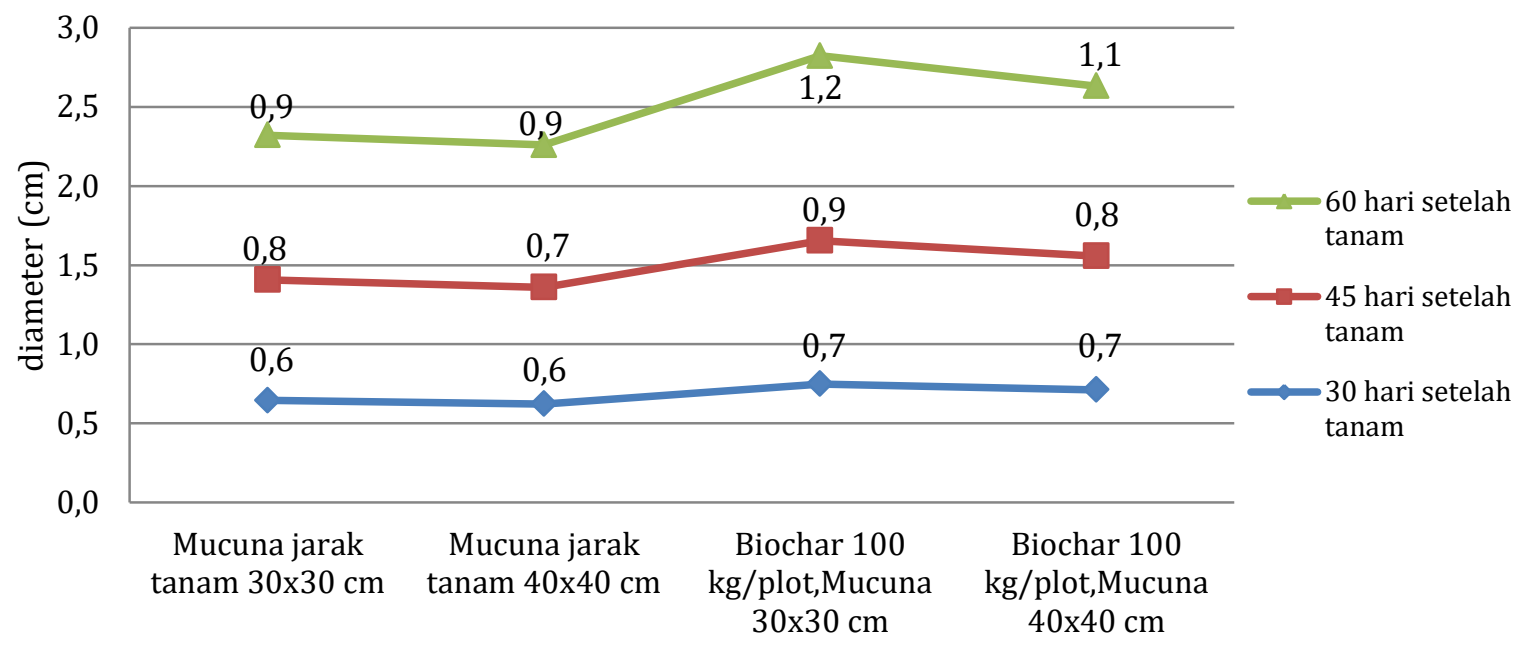

Gambar 3 Grafik rata-rata pertumbuhan diameter tanaman kenaf

Grafik rata-rata pertumbuhan tinggi tanaman (Gambar 4) kenaf terlihat bahwa pada hari ke-30 dan hari ke-45 setelah tanam rata-rata pertumbuhan tinggi masih didominasi oleh plot dengan perlakuan pemberian biochar $100 \mathrm{~kg} /$ plot dengan jarak tanam $40 \mathrm{~cm} \quad \mathrm{x} \quad 40 \mathrm{~cm}$, namun pada pengukuran selanjutnya pada hari ke 60 setelah tanam pertumbuhan paling baik adalah pada plot yang diberikan pembenah tanah Biochar sebanyak $100 \mathrm{~kg} /$ plot yang dikombinasikan dengan penanaman LCC jenis Mucuna sp dengan jarak tanam $30 \mathrm{~cm} \times 30 \mathrm{~cm}$.

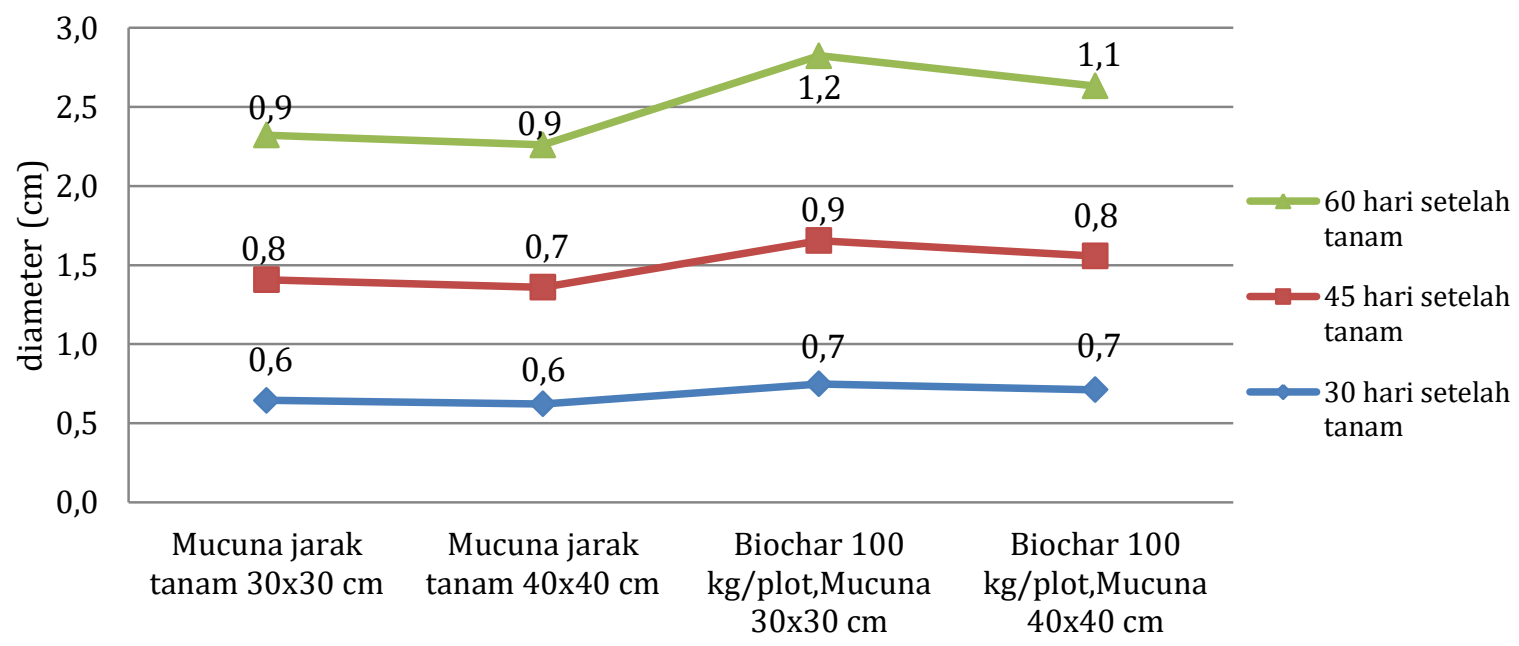

Gambar 4 Grafik Rata-Rata Pertumbuhan Tinggi Tanaman Kenaf 
Tinggi tanaman dan diameter batang merupakan sifat yang berpengaruh terhadap produksi serat. Hubungan produksi dengan panjang dan diameter batang bawah berkorelasi positif. Tinggi tanaman merupakan pencerminan dari panjang serat yang akan dihasilkan. Makin tinggi tanaman, maka makin panjang serat yang dihasilkan.

Tanaman kenaf varietas KR 11 memiliki keunggulan dalam hal produksi serat, karena batang tidak bercabang dan tahan terhadap fotoperiodisme, sehingga diharapkan mampu menghasilkan serat yang panjang dan berkualitas untuk pemanfaatan kenaf sebagai tanaman serat namun varietas ini hanya menghasilkan biji dalam yang sedikit karena biji hanya dihasilkan oleh tunas apikal saja sehingga kebutuhan akan benih kurang terpenuhi (Hidayati, 2009).

Hasil pengembangan uji coba budidaya tanaman kenaf pada lahan bekas penambangan batubara di Desa Tanah Datar dapat dikatakan cukup baik. Hal tersebut terlihat dari penampakan fisik tanaman kenaf serta pertumbuhan diameter dan tinggi tanaman kenaf yang ada, sehingga bisa dikatakan bila lahan pasca tambang batubara yang telah direklamasi tersebut layak untuk dikembangkan lebih lanjut dengan memperhatikan karakter tanah, iklim dan faktor pendukung lainnya.

\section{KESIMPULAN}

Tanaman kenaf mampu tumbuh dengan baik pada lahan pasca penambangan batu bara yang sebelumnya telah diberikan biochar dan ditanami jenis tanaman penyubur tanah jenis Mucuna sp, upaya ini merupakan alternatif yang menjadi pilihan karena mudah, murah dan efektif. Namun demikian, uji mutu dan ketahanan serat kenaf yang dihasilkan dari pengembangan kenaf pada lahan pasca tambang batubara Desa Tanah Datar Kecamatan Muara Badak Kabupaten Kutai Kertanegara Provinsi
Kalimantan Timur dianggap perlu untuk dilakukan.

\section{DAFTAR PUSTAKA}

Dariah, A., A. Abdurachman dan D. Subardja. 2010. Reklamasi lahan ekspenambangan untuk perluasan areal pertanian. Jurnal Sumberdaya Lahan 4 (1): 1-12.

Hidayati, Y. 2009. Kadar hormon auksin pada tanaman kenaf (Hibiscus cannabinus L) bercabang dan tidak bercabang. Jurnal Agrovigor 2(2): 89-96.

Juarsah, I. 2015. Teknologi pengendalian gulma alang-alang dengan tanaman legum untuk pertanian tanaman pangan. Jurnal Agro 2(1): 29-38.

Laird, D.A. 2008. The charcoal vision: a winwin-win scenario for simultaneously producing bioenergy, permanently sequestering carbon, while improving soil and water quality. Agronomy Journal 100: 178-181.

Margarettha, 2010. Pemanfaatan tanah bekas tambang batubara dengan pupuk hayati mikoriza sebagai media tanam jagung manis. Jurnal Hidrolitan 1(3): 1-10.

Purwati, R.D. 2009. Plasma nutfah kenaf (Hibiscus cannabinus L.). Monograf Balittas 1 (2): 13-26.

Sastrosupadi A, B. Santoso, dan Sudjindro. 1996. Budidaya Kenaf (Hibiscus cannabius L.). Monograf Balittas 1 (2): 29 - 41.

Steiner, C 2007. Soil charcoal amendments maintain soil fertility and establish carbon sink-research and prospects in Liu, T (Ed). Soil Ecology Research Development. p 1 - 6 . 